\title{
TELAAH PERAN ORGANISASI KEAGAMAAN DALAM PENGEMBANGAN PENDIDIKAN, SOSIAL, DAN DAKWAH
}

\author{
Oleh : Imam Suprayogo*)
}

\begin{abstract}
Abstrak
Pertanyaan yang selalu muncul seputer organisasi keagamaan adalah bagaimana sesungguhnya organisasi sosial keagamaan itu sendiri memiliki dan sekaligus mengembangkan kekuatan yang tangguh agar selalu dapat menyesuaikan dengan tuntutan zaman yang semakin maju dan rasional ini. Sebagai sebuah sistem, berbagai organisasi termasuk organisasi sosial keagamaan selalu memperoleh tantangan baik yang datang dari internal maupun eksternal. Organisasi akan tetap tumbuh kuat atau kukuh jika tetap memiliki sumber kekuatan penggerak berupa cita-cita, misi, atau visi yang jelas ke depan. Selain itu, ia tetap kuat jika mampu menyelesaikan berbagai tantangan yang datang dari dalam maupun dari luar itu sendiri.
\end{abstract}

\section{Kata Kunci: Organisasi Keagamaan, Pendidikan, Dakwah}

\section{Pendahuluan}

Sebagai salah satu kekayaan bangsa Indonesia, selain tanah yang subur, sumber alam yang melimpah, penduduk yang berjumlah besar, adalah organisasi sosial keagamaan yang tersebar di seluruh tanah air. Organisasi keagamaan itu misalnya, Nadhlatul Ulama', Muhammadiyah, Persis, Al Washliyah, dan Nahdhatul Wathan yang terdapat di Nusa Tenggara Barat ini.Organisasi keagamaanini pengaruhnya amat luas dan kuat di wilayah ini. Perannya cukup nyata. Hampir tak terbilang jumlah masjid, musholla, madrasah, sckolah, pondok pesantren, dan bahkan perguruan tinggi didirikan dan dikelola oleh lembaga sosial keagamaan ini. Sumbangan itu tidak saja dalam bentuk tempat ibadah, atau lembaga pendidikan, melainkan juga dalam bidang sosial, seperti pengelolaan zakat, pendirian panti asuhan, pemeliharaan orang lanjut usia, rumah sakit atau klinik kesehatan, yang kesemuanya itu jumlahnya amat besar.

Jurmal "El-Harakah" Vol. 5, No. 2, Juli - Oktober 2003 
Sumbangan organisasi sosial keagamaan seperti itu, selain memberi makna dalam kehidupan sosial secara nyata sebagaimana telah disebutkan itu, juga tak kurang penting artinya ialah telah menjadi perekat kehidupan bangsa secara keseluruhan. Kita lihat misalnya, dalam event muktamar organisasi itu para pengurus dan juga anggota, datang dari berbagaipenjuru tanah air. Mereka merasa berada dalam satu wadah organisasi yang dimiliki bersama. Mereka itu datang dengan biaya sendiri atau atas tanggungan organisasi untuk menyatukan rasa, pikiran, emosi dan program-program nyata yang dapat direalisasikan. Sebagai contoh, tatkala Nahdlatul Ulama mengadakan muktamar di Kediri, Jawa Timur beberapa waktu yang lalu, semua cabang dari seluruh penjuru tanah air datang. Mereka tak merasa terhambat oleh persoalanpersoalan politik dan bahkanjuga ekonomi. Sekalipun beberapa daerah sedang dilanda konflik yang menghkawatirkan terjadi disintegrasi bangsa, seperti di Aceh, Irian Jaya, Maluku, Riau dan sebagainya, ternyata mereka menghadiri acara itu. Demikian pula,tatkala Muhammadiyah menyelenggarakan Muktamar di Jakarta. Itulah yang saya katakan organisasi sosial keagamaan telah memberi sumbangan besar dalam ikut menjadi perekat kesatuan bangsa itu. Peran yang sama kiranya juga dimainkan oleh Nahdlatul Wathon di Nusa Tenggara ini.

Pertanyaan yang selalu muncul kemudian bagaimana sesungguhnya organisasi sosial keagamaan itu sendiri memilikidan sekaligus mengembangkan kekuatan yang tangguh agar selalu dapat menyesuaikan dengan tuntutan zaman yang semakin maju dan rasional ini. Sebagai sebuah sistem, berbagai organisasi termasuk organisasi sosial keagamaan selalu memperoleh tantangan baik yang datang dari internal maupun eksternal. Organisasi akan tetap tumbuh kuat atau kukuh jika tetap memiliki sumber kekuatan penggerak berupa cita-cita, misi, atau visi yang jelas ke depan. Selain itu, ia tetap kuat jika mampu menyelesaikan berbagai tantangan yang datang dari dalam maupun dari luar itu sendiri.

Berbagai organisasi memiliki kekuatan dan juga daya tahan yang berbeda. Suatu ketika, kita melihat organisasi lagi mengalami kemajuan, dan bahkan kejayaan. Tetapi sebaliknya, kita juga pernah menyaksikan suatu organisasi yang sedang mengalami kemunduruan dan bahkan jatuh mati. Oleh sebab itu, kita mengenal istilah zaman keemasan, zaman kemunduran, zaman pancaroba yang dialami oleh organisasi. Tidak saja hal itu dialami oleh organisasi keagamaan, tetapi juga oleh organisasi lainnya.

\section{Life Circle of Organization}


Jika kita mempelajari kehidupan organisasi , ternyata tergambar di sana bahwa organisasi itu tak ubahnya kehidupan makluk hidup seperti manusia, binatang, atau tumbuh-tumbuhan. Dalam teori organisasi, dikenal adanya lima tahap atau fase kehidupan organisasi. Masing-masing fase, biasanya, memiki ciri-ciri yang berbeda.

Kelima tahap fase kehidupan organisasi itu meliputi masa lahir, tumbuh, berkembang, dewasa dan menua, dan kemudian mundur dan mati. Sebagaimana kehidupan seseorang tatkala baru lahir, atau masih bayi memiliki ciri semangat hidup yang tinggi, kreatif, tetapi tidak memiliki tujuan yang jelas. Fase berikutnya adalah masa pertumbuhan. Pada fase ini, para ahli teori organisasi menyebut masa collectivity atau masa kebersamaan. Ciri organisasi adalah memiliki struktu, peran, serta pembagian tugas yang jelas. Akan tetapi oleh karena sudah semakin banyak orang yang terlibat dalam mengurus organisasi, maka para pendiri pada umumnya merasa khawatir, jangan-jangan cita-cita atau tujuan semula organisasi ini menjadi berbelok ke arah yang tak sesuai dengan tujuan semula.

Tahap berikutnya adalah fase pengembangan atau juga disebut formalization and control. Pada fase ini yang tampak jelas adalah penekanan pada peraturan-peraturan dan prosedur formal. Inovasi biasa kurang memperoleh perhatian, dan yang lebih dipentingkan adalah efisiensi dan stabilitas. Hal ini wajar dan gampang dimengerti karena organisasi sudah semakin besar. Menyusul tahap fornalisasi dan kontrol adalah fase dewasa. Ciri khas organisasi pada fase ini adalah adanya semangat memperluas pengaruh, dan organisasi menjadi membesar. Selain itu, hasil-hasil yang diraih mulai dirasakan. Ciri lainnya ialah bahwa orang-orang yang berada pada posisi penting, berusaha mengkalkulasi jasa yang telah diberikan, mempertahankan posisinya dengan berbagai cara. Orientasi seperti ini mengakibatkan konflikkonflik organisasi mulai timbul dan bahkan berkembang.

Jika suasana seperti itu telah mulai terjadi, biasanya organisasi sudah mulai memasuki fase, apa yang disebut dengan tahap kemunduran atau decline. Biasanya jika telah masuk fase ini konflik sudah mulai menajam, para elit biasanya berusaha berebut pengaruh. Mereka pada umumnya melupakan bahwa organisasi adalah sebagai alat untuk memperjuangkan nilai-nilai yang tinggi, bukan sekedar dijadikan untuk memperoleh keuntungan yang bersifat pribadi. Jika persoalan-persoalan itu tak kunjung terselesaikan, maka dinamika organisasi akan berhenti, bahkan akan mengalami kemunduran terus menerus, dan akhirnya mati atau mengalami masa keruntuhannya. 
Tahap-tahap kehidupan organisasi seperti itu memang tak dapat ditemukan dalam al Qur^an. Tetapi al Qur^an memberikan sinyal atau peringatan bahwa : likulli ummatin ajal, waidha jaa^a ajaluhum la yas ta^khiruuna sa^atan walaa yastaqdimuun. "Bahwa setiap ummat pasti menemui kematiannya. Jika telah datang kematian itu maka tak dapat diakhirkan atau dimajukan ".

Persoalannyaadalah, $\mathrm{jika}$ fase-fase kehidupan organisasi itu lita gunakan untuk melihat peran-peran organisasi keagamaan yang ada, maka kita secara kritis harus berani melihat, bahwa organisasi sosial keagamaan yang ada di Indonesia ini, masing-masing sedang berada pada fase mana ? Jika mereka berada pada fase akhir dewasa, apalagi menginjak fase decline, maka sulit dibayangkan oraganisasi dapat melakukan peran besar seperti apa, terutama dalam menumbuh-kembangkan lembaga pendidikan yang dimiliki, melakukan kegiatan dakwah dan juga mengembangkan program-program kegiatan sosial. Tatkala berada pada fase ini mereka sekedar mampu mempertahankan keberadaannya saja, dalam arti mampu menyelesaikan persoalan-persoalan internal saja sudah sangat besar. Jika organisasi sosial keagamaan tertentu, misalnya, sudah sampai pada fase menua, apa yang harus dilakukan? Atau, pertanyaan lainnya adalah dapatkah organisasi yang telah berada pada fase decline dimudakan kembali?

\section{Sumber Kekuatan Organisasi Sosial Keagamaan}

Semangat keberagamaan tampak sekali menjadi salah sumber kekuatan hidup organisasi keagamaan. Semangat itu juga melahirkan solidaritas sosial yang dibarengi dengan kekuatan berkorban yang tinggi. Atas dasar kekuatan itulah maka organisasi sosial keagamaan mampu melahirkan gerakan di berbagai bidang kehidupan. Berdirinya sekolah, madrasah, pondok pesantren, rumah sakit, panti asuhan, dan tempat ibadah yang berjumlah amat besar di berbagai wilayah adalah merupakan buah dari kekuatan yang bersumber dari keberagamaan itu. Niat untuk memperbanyak amal dan berkorban seringkali mengalahkan kepentingan yang bersifat pribadi.

Solidaritas seperti itu, ternyata dapat berubah seiring dengan perubahan masyarakatnya. Masyarakat yang homogin dilihat dari berbagai segi, misalnya jenis pekerjaan, kepercayaan atau keyakinan, sentimen dan sebagainya akan berbeda jika masyarakatnya sudah terdiferensiasi dalam pembagian kerja, tingkat pendidikan, dan sejenisnya. Durkheim membedakan jenis solidaritas itu menjadi solidaritas mekanik dan solidaritas organik. 
Masyarakat yang berada dalam solidaritas mekanik dapat digerakkan melalui sentimen atau emosi. Katakanlah, tatkala organisasi sosial keagamaan membuat rumah sakit atau lembaga pendidikan maka dukungan maupun pasar sebagai konsumen dapat digerakkan oleh sentimen atau emosi organisasi. Akan tetapi, hal itu akan semakin sulit jika masyarakat sudah memasuki fase solidaritas organik. Orang yang semula berada pada ikatan organisasi sosial keagamaan tertentu dapat diarahkan mendukung lembaga-lembaga yang dibangunnya tanpa reserve. Tetapi, hal itu akan sulit dilakukan dalam masyarakat yang mekanik. Sekalipun ia seorang anggota Muhammadiyah, misalnya, pilihan-pilihan terhadap layanan pendidikan ataupun kesehatan tidak selalu didasarkan atas pertimbangan afiliasi organisasi keagamaannya itu. Ia akan mempertanyakan secara rasional, tentang keuntungan maupun konsekuensi yang akan diperoleh. Fenomena seperti ini tentu harus dijadikan bahan pertimbangan dalam mengembangkan organisasi sosial keagamaan di manapun berada. Organisasi sosial keagamaan rupanya tak dapat bersikukuh mempertahankan kekuatan berupa solidaritas yang hanya didasarkan atas kepercayaan bersama, yakni cita-cita dan komitmen moral saja.

Selain itu, tampak bahwa dalam organisasi sosial keagamaan yang telah berkembang dan terdiferensiasi secara horisontal pada umumnya memiliki kekuatan yang beraneka ragam. Kita melihat, misalnya, terdapat beberapa wilayah yang mampu mengembangkan diri secara signifikan sehingga memilikei lembaga-lembaga pendidikan, sosial dan dakwah yang cukup maju, dan begitu pula sebaliknya, dialami oleh wilayah-wilayah lainnya. Perbedaan itu jika diamati secara jeli bukan saja diakibatkan oleh potensi alam yang berbeda, akan tetapi yang lebih menonjol adalah disebabkan oleh tersedianya sumber daya manusia yang berbeda. Organisasi sosial keagamaan lebih tampak digerakkan oleh orang-orang yang bersifat pribadi sekalipun mengatasnamakan organisasi. Orang-orang ini jumlahnya seringkali kecil, tetapi memiliki kekuatan yang luar biasa. Orang-orang yang memiliki kemampuan, kekuatan, dan peran penggerak organisasi seperti itu keberadaannya tidak merata di semua wilayah. Itulah yang mengakibatkan gerakan organisasi keagamaan antar masing-masing wilayah berbeda-beda.

Jika hasil pengamatan itu betul maka sesungguhnya, dapat disimpulkan bahwa kekuatan riil organisasi sosial keagamaan juga terletak pada tersedianya orang-orang yang memiliki potensi penggerak itu. Hanya eronisnya, dalam proses-proses sosial, tidak jarang kekuatan penggerak ini justru dilumpuhkan oleh kekuatan internal lain dalam proses perebutan pengaruh. Kasus seperti 
itu banyak ditemukan. Akibatnya, dalam organisasi terjadi stagnai secara berkepanjangan.

Mengenali sumber-sumber kekuatan organisasi ini amat penting sebagai modal upaya mendinamisasikan organisasi keagamaan. Tidak jarang terjadi organisasi sosial keagamaan pun hanya disibukkan oleh urusan-urusan para pengurus. Lebih dari itu, oleh karena tidak adanya kesadaran tentang betapa pentingnya manusia berkualitas sebagai asset organisasi, maka muncul perasaan sukses hanya karena telah mampu menyingkirkan seseorang dari kepengurusan organisasi. Pada hal keberhasilannya itu tidak mustahil justru berakibat pada mandelmya gerak organisasi itu sendiri.

\section{Memperbaharui visi dan misi}

Sudah menjadi watak organisasi sosial keagamaan, di mana saja berada, kelahirannya dimotivasi oleh keinginan untuk melakukan tugas mulia yaitu amar ma`ruf nahyu anil munkar, mengajak semua orang melakukan kebaikan dan mencegah hal yang tidak baik menurut ukuran agama. Akan tetapi pada tataran empirik, dalam organisasi tak jarang terjadi tarik menarik dalam memenuhi berbagai kepentingan, yaitu kepentingan organisasi ansikh dan atau kepentingan di luar itu yang kadangkala bersifat pribadi. Oleh karena itu, seringkali juga terdengar, dalam organisasi sosial keagamaan pun terjadi saling pengaruh-mempengaruhi antar elit, yang kadang juga berlanjut dengan konflik. Keadaan seperti itu, tak hanya terjadi dalam satu organisasi keagamaantertentu, melainkan juga terjadi di hampir semua organisasi keagamaan.

Mencermati kasus-kasus seperti itu, pertanyaan yang relevan diajukan adalah, bagaimana agar organisasi sosial keagamaan tak sampai mengalami decline. Atau, adakah pendekatan yang dapat dilakukan agar organisasi keagamaan tetap berada pada fase pertumbuhan atau kedewasaan? Sudah barang tentu, jawabnya adalah "bisa". Lalu bagaimana caranya ?

Menyelesaikan persoalan semacam itu, tentu tak mudah. Lebih-lebih lagi jika organisasi sosial keagamaan tersebut sudah berada pada fase bak pohon yang tak mampu lagi mengembangkan ranting, daun, dan juga berbuah. Untuk menghidupkan dan menyehatkan kembali, cara yang paling mudah, pohon itu harus dipotong. Jika hal itu dilakukan bisa jadi dari pohon tersebut akan muncul batang-batang baru atau rubus lagi. Artinya, pohon itu akan memiliki kekuatan hidup. Dalam hal kehidupan organisasi maka harus dicarikan kekuatan penggerak kembali, yaitu berupa kejelasan visi dan misinya itu. 
Jika mengikuti petunjuk ajaran agama hal itu dapat ditempuh lewat sillaturrahiem yang lebih intensif. Sebab, dengan sillaturrahiem akan lahir suasana taffahum. Suasana seperti itu akan membuahkan tadhommun dan atau tasamuh. Sikap seperti itu juga akan melahirkan pula tarrokhum, dan akhimya berlanjut dapat dibangun ta'awwun atau saling menolong. Jika hal itu dapat dilakukan, maka tepat pula apa yang disabdakan oleh Rasulullah saw., bahwa "barang siapa ingin diperpanjang umurnya dan juga dibanyakkan rezekinya maka sambunglah tali sillaturrahiem".

Lebih dari itu, terdapat petunjuk dalam Al Qur'an yang sedemikian jelas untuk menumbuh-kembangkan organisasi, yaitu yang dapat kita baca dalam surat al mudatsir ayat 1-7 (Artinya : 1. Hai orang yang berkemul.2. Bangunlah, lalu berilah peringatan! 3. Tuhanmu agungkanlah, 4. dan pakaianmu bersihkanlah, 5 . dan perbuatan dosa tinggalkanlah, 6 . dan jalanganlah kamu memberi (dengan maksud) memperoleh yang lebih banyak. 7. Dan untuk (memenuhi perintah) Tuhanmu, bersabarlah.

Ayat tersebut amat relevan jika dijadikan sebagai petunjuk bagi kita semua dalam mengembangkan organisasi, termasuk organisasi sosial keagamaan. Suatu ketika, sebuah organisasi sudah tidak dinamik, yang keadaannya bagaikan orang tua yang selalu berselimut. Selimut itu bisa dimaknai hal-hal apa saja yang menahan, mengikat, dan bahkan membelenggu. Oleh karena itu selimut itu harus segera disingkirkan. Orang-orang yang ada dalam organisasi harus segera bangkit, dan memberi peringatan kepada semua saja agar segera bergerak. Artinya, cita-cita, semangat, khayalan, dan pandangan ke depan, atau visi dan misinya harus segera digali dan ditegakkan kembali.

Visi dan misi awal setiap organisasi adalah mengagungkan asma Allah. Oleh sebab itu, semua yang terlibat dalam organisasi harus bersih, lahir dan batin. Semua yang terlibat dalam organisasi harus mampu menjauhkan kepentingan-kepentingan yang bersifat pribadi. Semua orientasi dikembalikan pada visi dan misi semula itu. Ayat tersebut juga memperingatkan bahwa dalam berjuang lewat organisasi harus selalu menghindar perbuatan tercela, dosa, dan hal-hal yang tak terpuji lainnya. Demikian pula, ayat al Qur'an tersebut juga memperingatkan agar kita tak terjebak pada langkah-langkah yang dapat dimaknai hanya mengejar keuntungan pribadi, lebih-lebih tatkala memberikan sesuatu kepada organisasi atau pihak lain. Jika mengikuti istilah sekarang, maka jangan terjebak pada kegiatan yang berbau KKN. Dan terakhir, masih dalam kontek ayat tersebut di atas, bahwa untuk memperjuangkan sesuatu yang mulia 
, baik sendiri maupun lewat organisasi keagamaan harus didasari oleh kekuatan, yaitu sifat sabar.

Demikianlah uraian singkat di seputar peran dan juga problem-problem organisasi sosial keagamaan. Semoga perbincangan ini dapat dijadikan sebagai salah satu pintu dalam memahami organisasi sosial keagamaan di tanah air ini. Selain itu, diharapkan pula dapat dijadikan bahan diskusi dan upaya melakukan gerakan revitalisasi organisasi keagamaan yang ada dalam menghadapi abad mendatang yang penuh dengan tantangan yang semakin luas dan kuat. Allahu a'lam bishawab.

*) Penulis adalah Rektor dan Guru Besar UIN Malang.

\section{DAFTAR PUSTAKA}

Al-Qur'an Al-Karim

Azra, Azyumardi. 1996, Pergolakan Politik Islam, Dari Fundamentalis, Modernis, Hingga Postmodernisme, Paramadina, Jakarta.

Dhafier, Zamakhsari, 1994, Tradisi Pesantren, Jakarta.

Geertz, Clifford, 1981, Abangan, Santri dan Priyayi dalam Masyarakat Jawa, Pustaka Pelajar, Jakarta.

Horikosi, 1987, Kiyai dan Perubahan Sosial, P3M, Jakarta

Noer, Deliar, Gerakan Modern Islam di Indonesia 1900 - 1942 